\title{
Invasive papillary breast carcinoma, solid variant with neuroendocrine differentiation
}

\author{
Fatma Şenel' ${ }^{1}$ Hatice Karaman¹, Mehtap Eroğlu' ${ }^{1}$ Ömer Tuna ${ }^{2}$
}

ABSTRACT
$\begin{aligned} & \text { Invasive papillary carcinoma, solid variant is a rarely observed breast tumor. It is encountered in patients of ad- } \\ & \text { vanced ages and has a good prognosis. After the physical examination, mammography, and ultrasonography exami- } \\ & \text { nations, modified radical mastectomy were applied to the } 72 \text {-year-old patient, who came to our hospital complain- } \\ & \text { ing of a mass in the left breast. During the macroscopic analysis, a well-limited, necrotic, and bleeding tumor with } \\ & \text { a diameter of } 7 \mathrm{~cm} \text { was found in the left breast, covering almost the whole area. The case was diagnosed as invasive } \\ & \text { papillary carcinoma, solid variant with neuroendocrine differentiation, which has been reported in the literature as } \\ & \text { a result of the histopathological and immunohistochemical analysis. } \\ & \text { Keywords: Breast carcinoma, papillary carcinoma, solid variant }\end{aligned}$

Cite this paper as: Senel F, Karaman H, Eroğlu M, Tuna O. Invasive papillary breast carcinoma, solid variant with neuroendocrine differentiation. Turk J Surg 2017; 33: 302-304.

'Clinic of Pathology, Kayseri Training and Research Hospital, Kayseri, Turkey

${ }^{2}$ Clinic of General Surgery, Kayseri Training and Research Hospital, Kayseri, Turkey

Address for Correspondence Fatma Şenel e-mail:drfatmasenel2@gmail.com

Received: 19.01.2015

Accepted: 21.03.2015

Available Online Date: 14.07.2015

(c) Copyright 2017

by Turkish Surgical Association

\section{INTRODUCTION}

Papillary carcinoma, which constitutes $1-2 \%$ of the breast cancers observed in women, has usually a good prognosis with low grade nuclear features (1). Almost half of the papillary carcinomas develop from the center of the breast. It is observed as a round and well-limited mass on mammography. There can be a cystic area in most of the papillary carcinomas, but this is not necessary; there may be a minimum cyst formation or it may never be seen. Papillary carcinomas are divided into two categories such as invasive and noninvasive. There are no papillary structures in the histopathological appearance of the papillary carcinoma; it is called solid papillary carcinoma. Solid papillary breast carcinoma is encountered at more advanced ages than other breast carcinoma cases; the average age range is 63-71 years. Invasive papillary carcinoma, solid variant is a rarely seen breast tumor with a good prognosis. The average size of the tumors is $2-3 \mathrm{~cm}$. Big tumors can fill the whole breast. Fibroadenoma, benign cystic lesions, mucinous, and medullary carcinoma must be considered in the differential diagnosis (2). In this case, we diagnosed invasive papillary carcinoma, solid variant with neuroendocrine differentiation in the 72-year-old patient, who had a mass with a $7 \mathrm{~cm}$ diameter in the left breast.

\section{CASE PRESENTATION}

The 72-year-old female patient presented to our hospital with the complaint of a mass, pain in her left breast, and bloody nipple discharge, which had been noticed for 2 months. A mass was detected during the examination, which was fixed in the breast and filled almost all of it. An approximately $7-\mathrm{cm}$ hypoechoic lesion was found on ultrasonography, which was filling the left breast and a $28 \times 16 \mathrm{~mm}$ lymph node was detected in the left axillary tail. An approximately $7 \mathrm{~cm}$ nodular radioopacity was found in her mammography, which was filling the left breast, and a $28 \times 16 \mathrm{~mm}$ lymph node was detected in the left axillary tail.

Modified radical mastectomy was applied to the left breast of the patient. Fine needle aspiration or trucut biopsy was not performed preoperatively. Macroscopically, a $7 \times 5 \times 5 \mathrm{~cm}$ sized, properly-limited, necrotic and locally bleeding tumor was found on the incision site of the $19 \times 9 \times 6 \mathrm{~cm}$ mastectomy material, which covered the upper and lower inner quadrants and reached the outer quadrants, and 10 lymph nodes were removed from the axilla. The tumor was seen in some areas during the microscopic analysis; these tumors had invasion to the surrounding tissue (Figure 1), formed solid islands, lobules and nests, had an oval nucleus, showed a slight pleomorphism, and comprised of noticeable cells with local nucleoli (Figure 2).

Wide necrosis areas and bleeding was observed within the tumor. A metastatic axillary lymph node was found. In the immunohistochemical analysis, the epithelial membrane antigen, pancytokeratin, was diffuse positive and cytokeratin-18 was positive (Figure 3), NSE was focal positive (Figure 4). E-cadherin was weak positive, S-100 protein, synaptophysin, vimentin, and cytokeratin- 5 were negative. Smooth muscle actin and myoepithelial cells were not detected. Estrogen and progesterone receptor was positively stained, whereas cerbB2 was negatively stained. Ki67 proliferation index was around $10 \%$. With PAB and mucicarmine stains, mucin accumulation was not observed on histochemical analysis. As a result of all 


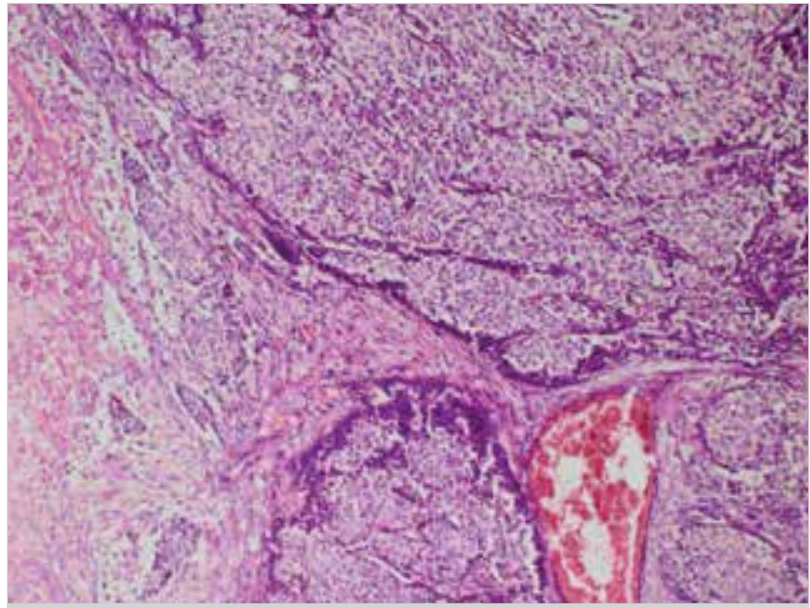

Figure 1. Invasion of the surrounding tissue $(H \& E: \times 10)$

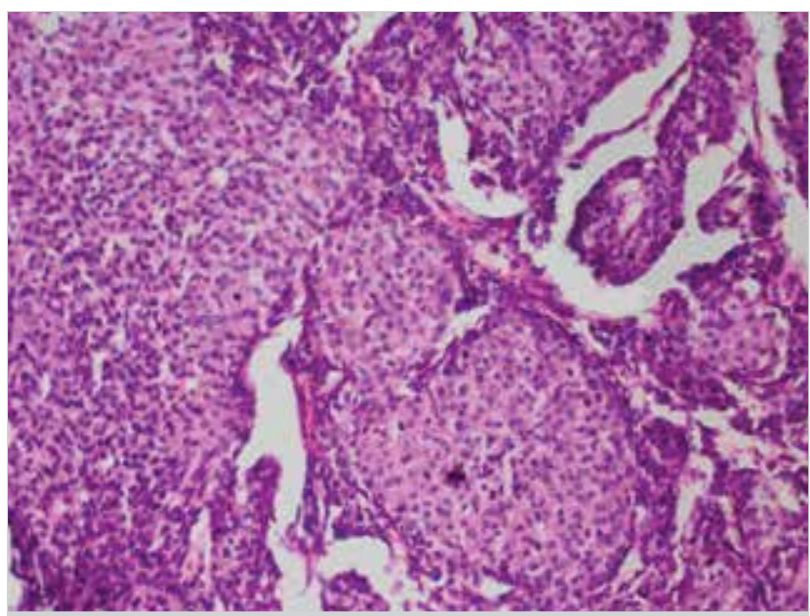

Figure 2. Round tumor with oval nucleus and slight pleomorphism, forming solid islands, lobules, and nests $(H$ \& $\mathrm{E}: \times 20)$

these morphological and immunohistochemical findings, the case was evaluated as invasive papillary carcinoma, solid variant with neuroendocrine differentiation.

\section{DISCUSSION}

Papillary carcinoma constitutes 1-2\% of the breast carcinomas in women (1). Solid variant forms less than $1 \%$ of the breast carcinomas. Similar to our case, it is mostly seen in postmenopausal women and is frequent in the $7^{\text {th }}$ decade $(3,4)$.

Approximately $50 \%$ of the papillary carcinomas develop from the central part of the breast; nipple changes are observed in one-third of the patients $(2,3)$. Our patient also presented with bloody nipple discharge and a mass.

Papillary carcinomas may histopathologically show papillary, micropapillary, cribriform, reticular, and solid appearance. Solid variant is mostly well-limited and frequently multinodu$\operatorname{lar}(2)$. In the histopathological appearance of the solid papillary carcinoma, the tumor comprises of cellular islands, ductal structures, and intensive fibrous connective tissues between them. The cellular islands seem noninvasive because they are well-limited, but generally, no peripheral myoepithelial cell layers are observed with immunohistochemical staining (5). The cellular proliferations in the tumor nodule are homogenous and adjacent to each other; there are no cribriform or

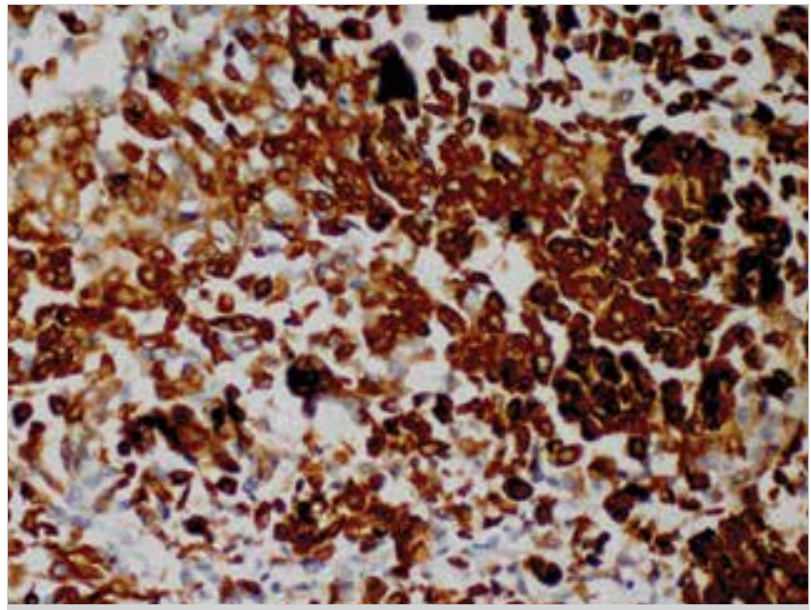

Figure 3. Positive staining with CK18 in tumor cells $(\times 40)$

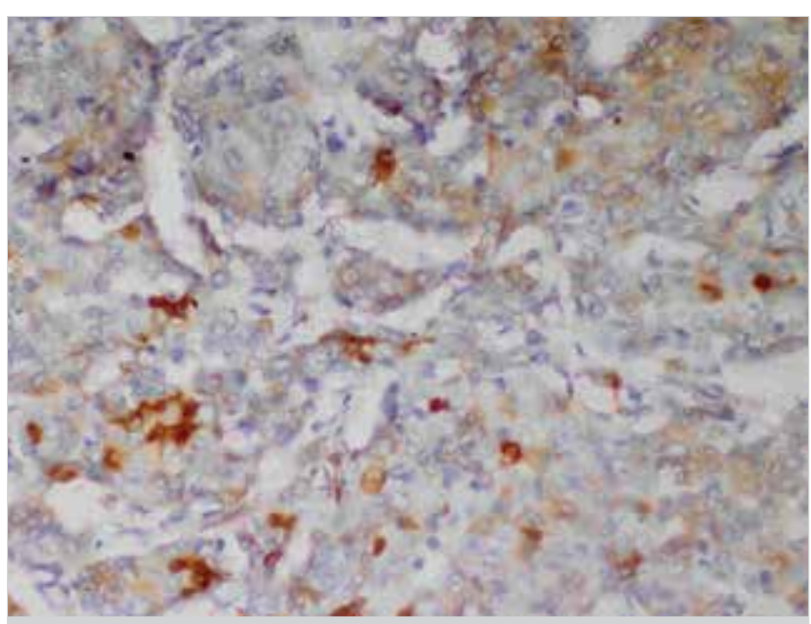

Figure 4. NSE positivity $(\times 40)$

papillary patterns (6). The cells are small and have hyperchromatic nuclei. Signet ring cell forms can also be observed and the number of mitoses is generally low (7).

Papillary carcinomas may exist in at least half of the neuroendocrine differentiation cases. NSE, chromogranin, and/or synaptophysin stainings are detected. In our case, neuroendocrine differentiation was present and focal NSE staining was observed (8). Similar to our case, estrogen and progesterone receptor are positive and HER2 is negative in the solid papillary carcinoma (6). Moreover, CK8 and CK18 are positive $(9,10)$. In our case, CK18 was stained diffuse-strong positively. Microscopic diagnosis of the invasive papillary carcinoma is difficult. Nonexistence of the myoepithelium layer and the muscle and adipose tissue invasion of the tumor in its periphery are important for the diagnosis (2). Invasive or in situ differentiation cannot be made with the needle biopsy or the cytology materials; this differentiation can only be made within the excision material (2).

Intraductal papilloma and generalized ductal hyperplasia must also be considered in the differential diagnosis. Myoepithelial cells exist in benign papillary lesions but not in the papillary carcinoma. Immunohistochemically, high-molecularweight keratin negativity distinguishes the solid papillary carcinoma from proliferative lesions (11). Medullary carcinoma and mucinous carcinoma are the tumors, which must also be considered in the differential diagnosis. 
Prognosis of papillary carcinoma is better when compared to invasive ductal carcinoma (12).

Patients with axillary lymph node metastasis at the rate of 20-32\% have been reported (13). A metastatic axillary lymph node was found in our case. Solid papillary carcinoma and cystic papillary carcinoma result in local recurrences with similar frequencies, but those with solid papillary carcinoma were more likely to have axillary lymph node and systemic metastasis and to die of metastatic carcinoma (2).

Prognosis with lumpectomy is perfect in invasive or noninvasive carcinomas. The relapse risk is high in multifocal masses. According to the study results of Nassar et al. (4), hormonal and/or chemotherapy application to invasive solid papillary carcinoma patients without paying attention to lymph node involvement was considered appropriate. Modified radical mastectomy was conducted in our case. According to the American Joint Committee on Cancer 2010, the patient was pT3N1 (stage IIIA). Because of the good general status of the patient, oncologists decided to give chemotherapy treatment regardless of old age and chemotherapy was applied after 2 months. She is alive with no recurrence at 25 months.

\section{CONCLUSION}

Invasive papillary carcinoma, solid variant is seen in women at advanced ages and has a good prognosis. It must be considered during the differential diagnosis of benign and malign breast tumors. Invasive or in situ differentiation cannot be made with the needle biopsy or the cytology materials; this diagnosis can only be made within the excision material.

Informed Consent: Written patient consent could not be obtained for the patient and their relatives could not be reached.

Peer-review: Externally peer-reviewed.

Author Contributions: Concept - F.Ş., H.K., M.E.; Design - F.Ş., H.K., Ö.T.; Supervision - F.Ş., H.K., Ö.T.; Materials - F.Ş., Ö.T.; Data Collection and/ or Processing - F.Ş., H.K., Ö.T.; Analysis and/or Interpretation - F.Ş., H.K., M.E.; Literature Review - F.Ş., H.K., Ö.T.; Writer - F.Ş., H.K.; Critical Review - F.Ş., M.E., Ö.T.

Conflict of Interest: No conflict of interest was declared by the authors.
Financial Disclosure: The authors declared that this study has received no financial support.

\section{REFERENCES}

1. Dursun N, Gücin Z, Özcan M, Özgün Geçer M, Güzel Çay T, Bahadır $\mathrm{F}$, ve ark. Invaziv papiller meme karsinomu-solid varyant: Olgu sunumu. J Breast Health 2007; 3: 145.

2. Rosen PP. Papillary carcinoma. Rosen's breast pathology 3rd ed. Philadelphia, Lippincott Williams \& Wilkins 2009; 423-448.

3. Maluf HM, Koerner FC. Solid papillary carcinoma of the breast. A form of intraductal carcinoma with endocrine differentiation frequently associated with mucinous carcinoma. Am J Surg Pathol 1995; 19: 1237-1244. [CrossRef]

4. Nassar H, Qureshi H, Adsoy NV, Visscher D. Clinicopathologic analysis of solid papillary carcinoma of the breast and associated invasive carcinomas. Am J Surg Pathol 2006; 30: 501-507. [CrossRef]

5. Nicolas MM, Wu Y, Middleton LP, Gilcrease MZ. Loss of myoepithelium is variable in solid papillary carcinoma of the breast. Histopathology 2007; 51: 657-665. [CrossRef]

6. Lakhani SR, Ellis IO, Schnitt SJ, Tan PH, Vijver MJ. WHO classification of tumors of the breast. International agency of research on cancer Lyon 2012; 108-109.

7. Farshid G, Moinfar F, Meredith DJ, Peiterse S, Tavassoli FA. Spindle cell ductal carcinoma in situ. An unusual variant ductal intra-epithelial neoplasia that simulates ductal hyperplasia or a myoepithelial proliferation. Virchows Arch 2001; 439: 70-77. [CrossRef]

8. Otsuki Y, Yamada M, Shimizu S, Suwa K, Yoshida M, Tanioka F, et al. Solid-papillary carcinoma of the breast: clinicopathological study of 20 cases. Pathol Int 2007; 57: 421-429. [CrossRef]

9. Moritani S, Ichihara S, Kushima R, Okabe H, Bamba M, Kobayashi TK, et al. Myoepithelial cells in solid variant of intraductal papillary carcinoma of the breast: a potential diagnostic pitfall and a proposal of an immunohistochemical panel in the differential diagnosis with usual ductal hyperplasia. Virchows Arch 2007; 450: 539-547. [CrossRef]

10. Weigelt B, Geyer FC, Horlings HM, Kreike B, Halfwerk $H$, Reis-Filho JS. Mucinous and neuroendocrine breast carcinomas of no special type. Mod Pathol 2009; 22: 1401-1414. [CrossRef]

11. Rabban jT, Koerner FC, Lerwill MF. Solid papillary ductal carcinoma in situ versus usual ductal hyperplasia in the breast: a potentially difficult distinction resolved by cytokeratin 5/6. Hum Pathol 2006; 37: 787-793. [CrossRef]

12. Taşdemir A, Soyuer I, Karaman H, Öztürk F. A rare case: Invasive papillary carcinoma of breast. Diagnostic clues in fine needle aspiration cytology. J Breast Health 2010; 6: 83-86.

13. Tavassoli FA. The pathology of breast. Connecticut: Appleton \& Lange 1992; 193. 